\section{Estudo \\ CoDebate}

em CAStão

Plamejamento
Revista Estudo \& Debate, Lajeado, v. 27, n. 3, 2020. ISSN 1983-036X

DOI: http://dx.doi.org/10.22410/issn.1983-036X.v27i3a2020.2487

\title{
EXPORTAÇÓES, INSERÇÃO COMERCIAL E ESPECIALIZAÇÃO PRODUTIVA: UMA ANÁLISE PARA OS PRODUTOS PRIMÁRIOS BRASILEIROS ENTRE 2001 E 2016
}

\author{
Mattheus Rodrigues da Silva ${ }^{1}$, Ricardo Schmidt Filho ${ }^{2}$, Danyelle Mestre de Souza ${ }^{3}$, \\ Flávio Kauê Targino Bezerra ${ }^{4}$
}

\begin{abstract}
Resumo: Dentro do campo da economia internacional, existe um extenso debate a respeito da especialização produtiva. Enquanto correntes teóricas de cunho mais ortodoxo defendem a inserçáo comercial com base nas vantagens competitivas, correntes de cunho mais estruturalista defendem um método de inserção com base em setores com maior valor agregado intensivos em tecnologia. No caso brasileiro, os produtos primários/agrícolas são historicamente de relativa importância para a balança comercial e para a estrutura produtiva do país como um todo. $\mathrm{O}$ período analisado, traz uma série de fatos que estimulam a produçáo de produtos primários, em especial o movimento de apreciação dos preços das commodities e a intensificação do processo de industrializaçáo da economia chinesa. Dessa forma, se faz necessário verificar como ocorre a inserção desses produtos (primários) brasileiros no comércio exterior, focando em aspectos como: parcela do mercado e competitividade e qual a implicaçáo desse modelo de inserçáo sobre o desenvolvimento do país.. Para atingir os resultados, utilizouse de indicadores de comércio internacional MS, IVCR e CS. Verificou-se que a inserçáo comercial ocorre especialmente através de produtos voltados para a alimentaçáo em sua maioria in natura, destacando a presença de produtos "tradicionais" como o açúcar, o café e o tabaco e produtos inseridos recentemente como o complexo da soja e das carnes. Por fim, a principal conclusão desse trabalho é que por mais que alguns produtos apresentem resultados expressivos, de modo geral, o setor apresenta um alto grau de concentração e pouca dinâmica.
\end{abstract}

Palavras-chave: Produtos primários. Exportaçōes. Competitividade. Saldo Comercial. Setorial.

1 Mestre em Economia pela Universidade Federal do Rio Grande do Norte (UFRN). E-mail: mattheusr36@gmail.com

2 Professor Doutor do Departamento de Economia da Universidade Federal de Campina Grande (UFCG). E-mail: rschmidtfilho@hotmail.com

3 Mestranda em Economia Regional pela Universidade Federal do Rio Grande do Norte. E-mail: danyelle_dms@hotmail.com

4 Mestrando em Economia Regional pela Universidade Federal do Rio Grande do Norte. E-mail: flaviokauetb@hotmail.com 


\title{
EXPORTS, COMMERCIAL INSERTION AND PRODUCTIVE SPECIALIZATION: AN ANALYSIS FOR BRAZILIAN PRIMARY PRODUCTS BETWEEN 2001 AND 2016
}

\begin{abstract}
Within the field of international economics, there is an extensive debate regarding productive specialization. While more orthodox theoretical currents advocate commercial insertion based on competitive advantages, more structuralist currents advocate an insertion method based on sectors with higher technologyintensive added value. In the Brazilian case, primary / agricultural products have historically been of relative importance for the trade balance and for the productive structure of the country as a whole. The analyzed period, brings a series of facts that stimulate the production of primary products, especially the movement of appreciation of the prices of the commodities and the intensification of the industrialization process of the Chinese economy. Thus, it is necessary to verify how these (primary) Brazilian products are inserted in foreign trade, focusing on aspects such as: market share and competitiveness and what the insertion model implies on the country's development. To achieve the results, used international trade indicators MS, IVCR and CS. It was found that the commercial insertion occurs especially through food products, mostly in natura, highlighting the presence of "traditional" products such as sugar, coffee and tobacco and products inserted recently, such as the soy and meat. Finally, the main conclusion of this work is that, although some products present expressive results, in general, the sector presents a high degree of concentration and little dynamics.
\end{abstract}

Keywords: Primary products. Exports. Competitiveness. Trade balance. Sectorial.

\section{INTRODUÇÃO}

A especialização produtiva e seus efeitos estáo dentro de um longo, mas, ainda atual debate dentro da ciência econômica. Em meio a uma série de interpretaçóes a respeito dos impactos da especialização comercial sobre as economias, destaca-se o embate entre as correntes de pensamento de cunho estruturalista, e as teorias clássicas e neoclássicas do comércio internacional - por divergir em uma série de constataçóes, mas, especialmente a respeito das implicaçôes da especialização produtiva.

Tanto as teorias clássicas quanto as neoclássicas, apontam a especialização comercial baseada em vantagens competitivas, como o caminho a ser trilhado pelas naçóes, de modo que, o comércio internacional, viria a ser uma forma de explicitar as potencialidades naturais de cada país, e prover o aumento do bem estar social das naçóes que dele participam. Enquanto a teoria cepalina, ao adotar uma visão de cunho estruturalista, contesta esse tipo de especialização como estratégia de desenvolvimento, dada a dinâmica ocasionada com as inovaçóes tecnológicas, e a presença de uma assimetria nos ganhos, para os diferentes tipos de produtos.

De modo que, para países especializados em produtos manufaturados e intensivos em tecnologia, o progresso técnico possibilita um aumento nos lucros e nos salários dos trabalhadores, enquanto para países especializados em produtos primários/agrícolas esses ganhos redundam em reduçáo de preços. Dada a atual configuração da economia mundial e a importância do intercâmbio comercial, essas disparidades qualitativas tendem a resultar em recorrentes déficits comerciais para os países especializados em atividades primárias.

Ao longo do tempo os produtos primários representaram o motor da economia brasileira, que por sua vez historicamente dependeu dos ciclos econômicos destes produtos, assim como foi com o pau-brasil, açúcar, ouro, café e mais recentemente com a soja. Estes 
produtos, cada um em seus ciclos respectivos, sempre ostentaram uma grande participação na concentrada pauta de exportaçóes brasileiras.

Os primeiros anos do século XXI se caracterizam por maior incentivo à produção de produtos primários para a economia brasileira, com o início do ciclo de alta dos preços das commodities e com a intensificação do processo de industrialização da economia chinesa, que passou a demandar cada vez mais produtos primários, demanda essa suprida principalmente pela economia brasileira. Nesse contexto, esse trabalho busca responder os seguintes questionamentos: quais as principais características da inserção de produtos primários brasileiros no comércio internacional? e esse tipo de inserção é capaz de promover o desenvolvimento do país?

Com o intuito de responder tal problema, serão utilizados nesta pesquisa indicadores de comércio internacional, que serão: Índice de Vantagens Comparativas Reveladas (IVCR), Índice de Contribuição ao Saldo (CS) e o Market Share (MS). De modo que, espera-se que os resultados desse trabalho siga o que se observa na maioria dos países "primárioexportadores", onde a especialização produtiva não é capaz de prover uma melhora da estrutura produtiva/pauta de exportaçóes do país, corroborando com aquilo que é apontado pelas teorias da corrente estruturalista.

Além dessa seção introdutória, este trabalho está dividido da seguinte forma: uma seção de cunho teórica, que apresenta aspectos que determinam as teorias de comércio exterior, bem como uma breve exposição das mesmas. Seguida por uma seção histórica, que traz um breve resgate da importância dos produtos primários para a economia brasileira ao longo do tempo - e uma seçáo de cunho de cunho conjuntural, que buscará apresentar um panorama do setor externo brasileiro no período analisado. Por fim, tem-se a análise e interpretação dos resultados obtidos dos indicadores de comércio exterior utilizados no trabalho e uma seção com as considerações finais.

\section{A IMPORTÂNCIA DO COMÉRCIO INTERNACIONAL: TEORIA CLÁSSICA X TEORIA CEPALINA}

O comércio de mercadorias é umas das atividades econômicas mais antigas. De acordo com Poyer e Roratto (2017, p. 9), os primeiros registros de comércio datam no ano 2000 a.C. na civilização fenícia, entretanto, a atividade só se consolida através da "revolução comercial”, que teve início ainda no século XI, e toma proporçóes globais com o início das grandes navegaçóes no século XV (FOURQUIN, 1981; BRESSER-PEREIRA, 2016).

No contexto do comércio entre nações, os primeiros debates surgem no período da gênese da ciência econômica, dentro do contexto mercantilista, e se estendem até os dias atuais. De modo que, segundo Krugman e Obstfeld (2010, p. 1) "[...] a disciplina economia como a conhecemos, começou a partir do estudo do comércio e das finanças internacionais". Sendo assim, estudar as relações de comércio entre países é de extrema importância, conforme afirma Oliveira (2007, p. 2):

[...] Entender o porquê da existência de comércio entre as nações, seus fundamentos básicos, o padrão de comércio, quais os preços das exportações/importações, que quantidades são ou poderiam ser exportadas/importadas, quais são as diretrizes determinantes da política 
comercial dos países. Estes sáo alguns dos questionamentos básicos quando dos estudos das teorias do comércio internacional. As teorias buscam justamente demonstrar o porquê da existência do comércio e quais seus benefícios reais e seus custos para o crescimento econômico da nação.

Autores da chamada "Economia Clássica", como Smith (1963) e Ricardo (1981) através das teorias das Vantagens Absolutas e Comparativas, respectivamente, são responsáveis pelas primeiras teorias formais, que se propuseram entender a dinâmica da relação de trocas entre as naçôes. Baseadas em diferenças na produtividade do trabalho, tais ideias ainda possuem grande peso no cerne que sustenta as teorias modernas de comércio internacional, especialmente as teorias de caráter neoclássico.

Outra contribuição importante é o modelo Hecksher-Ohlin, também conhecida como teoria da dotaçáo relativa dos fatores. Pertencente a escola neoclássica de comércio internacional, tal teoria avança, ao incorporar mais fatores de produção, além do trabalho, de modo que, as decisões de produção são tomadas de acordo com a escassez ou abundância do fator de produção necessário para a produção, com isso as vantagens sempre serão dos setores que produzem produtos intensivos no fator abundante (SARQUIS, 2011).

Uma visão alternativa a essa ideia pode ser vista através dos escritos dos autores da Comissão Econômica Para a América Latina e o Caribe (CEPAL), que divergem dos autores clássicos, por adotar uma visão de cunho estruturalista a respeito do comércio internacional, especialmente das implicaçôes da especialização comercial. Um dos pilares para o desenvolvimento do pensamento cepalino é a concepção de Prebisch a respeito da configuração da economia mundial, essa visão vem a fazer frente às ideias smithianas e ricardianas, que propóem que o subdesenvolvimento se configura em um estágio a qual todas as economias devem passar rumo ao caminho do desenvolvimento econômico.

Prebisch (2000) visualiza a economia mundial dividida em dois grupos de países: o centro e a periferia. Os países de centro são países desenvolvidos, detentores de um setor industrial robusto e com alto grau de inovação, enquanto os países que compóe a periferia são caracterizados por países subdesenvolvidos (ou em desenvolvimento), com economias agroexportadoras, especializados na produçấo de produtos básicos, em suma commodities agrícolas e minerais, que não desfrutam ou desfrutam muito pouco do progresso técnico.

A teoria clássica de comércio internacional não visualiza nada de anormal nessa relação existente entre esses grupos de países, tendo em vista que cada país se insere no comércio exterior com aqueles produtos a qual possuem vantagens produtivas, e que a especializaçáo tende a tornar os países mais eficientes do ponto de vista produtivo. Enquanto na visão cepalina, existe um fator que tende a agravar as disparidades entre as naçóes desenvolvidas e as subdesenvolvidas que é a diferença qualitativa e quantitativa existente entre produtos manufaturados e produtos primários.

Oaumento da disparidade ocorre através do fenômeno denominado por Prebisch como "deterioração dos termos de troca". Tendo em vista que, os ganhos provenientes do progresso técnico não se dividem de forma igualitária entre os setores da economia (LANNONE, 2006).Ou seja, a tendência natural é que, os preços dos produtos manufaturados subam, 
possibilitando um aumento nos lucros e nos salários dos trabalhadores, enquanto, nos setores agrícolas, os ganhos são normalmente dissipados nos preços, que tendem a cair.

Outra tendência que surge para os países da periferia o desequilíbrio externo, pela própria característica desses países de exportar produtos de baixo valor agregado e com baixa elasticidade renda, e importar produtos de alto valor agregado com alta elasticidade renda. Desse modo, as divisas obtidas através das exportaçôes serão insuficientes para fazer frente às necessidades de importação para suprir a demanda interna. Tal situação força as economias da periferia a compensar essa falta de divisas através da conta de capitais, deixando-as ainda mais vulneráveis, como pode ser observado na crise dos países emergentes da década de 90 .

De acordo com a visão cepalina, cabe ao Estado agir no sentido de reduzir as disparidades existentes. Neste sentido, a solução apontada para superar o subdesenvolvimento é a industrialização. Medidas protecionistas deveriam ser tomadas para garantir o amadurecimento da indústria local, como a proteção a indústria infante. Conforme mostra Colisete (2001, p. 24), a industrialização "poderia dar origem a um círculo virtuoso de crescimento da produtividade, do emprego e da renda”.

Reinert (2016, p. 335) contribui com o debate problematizando as características das políticas de desenvolvimento econômico nos últimos anos. O autor destaca que questóes de suma importância para a redução das disparidades são negligenciadas nas atuais formas de combater o subdesenvolvimento. Onde, os setores agroindustriais, sozinhos, não possuem sustentação para fortalecer uma economia - de modo que, para uma economia agroexportadora que possui um setor industrial incipiente, é mais prudente promover a industrialização, do que se render a especialização agrícola e adentrar no círculo vicioso característico das economias que optam por este tipo de especialização.

Tanto as teorias clássicas, quanto as neoclássicas apontam a especialização comercial baseada em vantagens competitivas, como o caminho a ser trilhado pelas naçóes, de modo que, o comércio internacional, viria a ser uma forma de explicitar as potencialidades naturais de cada país, e prover o aumento do bem estar social das naçóes que dele participam. Enquanto a teoria cepalina, ao adotar uma visão de cunho estruturalista, contesta a especialização como estratégia de desenvolvimento, dada a dinâmica ocasionada com as inovaçóes tecnológicas, e a presença de uma assimetria nos ganhos, para os diferentes tipos de produtos.

\section{INSERÇÃO BRASILEIRA NO COMÉRCIO EXTERIOR ATRAVÉS DE PRODUTOS PRIMÁRIOS: ASPECTOS HISTÓRICOS}

O setor primário é historicamente importante para a economia brasileira, se configura ao longo do tempo como um dos principais fornecedores de divisas estrangeiras por meio dos superávits comerciais. Tal fato confirma que o Brasil segue a lógica da escola cepalina, que em suma afirma que as economias subdesenvolvidas e em especial as economias latino americanas possuem um setor primário dinâmico, mas incapaz de promover o progresso técnico para o resto da economia, impedindo-a de desfrutar no longo prazo de avanços econômicos e sociais (COLISETE, 2001). 
O período caracterizado como "Economia Agroexportadora escravista" (1820-1889) se trata do estágio inicial da atividade no país, e apenas quatro produtos eram responsáveis por boa parte dos fluxos comerciais. Esses produtos eram: o açúcar, o algodáo e o café, de modo que a partir de meados de 1850 , a borracha também passa a desempenhar um papel importante. Consequentemente, neste período, a demanda por produtos manufaturados era quase que totalmente suprida pelas importaçóes (ABREU; LAGO, 2014).

Na "Primeira República" (1890-1929), verifica-se a ascensão da economia cafeeira, que se consolida como principal produto exportado. Tal produto contava com um cenário externo favorável e com políticas voltadas para seus produtores. O ciclo da borracha fez com que o produto despontasse como um dos principais produtos exportados pelo país na primeira república, este ciclo se iniciou ainda no fim do período colonial fez com que a borracha se sustentasse durante muito tempo como um dos principais produtos exportados pela economia brasileira, ficando atrás apenas do café. Produtos como açúcar, fumo, algodão, mate e couros e peles, juntamente com o café e a borracha, na média para o período, foram responsáveis por cerca de $90 \%$ das exportaçóes totais (ANTONIO FILHO, 2010; VILELLA; SUZIGAN, 1975).

O ano subsequente é marcado pela "Crise de 29", resultando no esgotamento do chamado "modelo primário-exportador", e na reorientação da economia brasileira, através de um Processo de Substituição de Importaçóes (PSI). De acordo com Furtado(1976, apud RAMOS, 2009, p. 2): "A economia brasileira embarcou em novo "modelo" de crescimento, cujo marco foi a mudança de centro dinâmico, o qual passou a ser caracterizado pela importância do processo de industrialização e da expansão do mercado interno".

Ao analisar a expansão da produção agrícola brasileira entre 1930 e o início dos anos 2000, Ramos (2009) divide tal processo em quatro recortes, onde, o primeiro período 1930 a 1960 houve uma expansão da produção agrícola, porém voltada para a demanda interna. A década de 60 representa um período de transiçáo, através da criação, por meio do Estado, de um ambiente para a elevação dos rendimentos agropecuários, mas ainda com enfoque no mercado interno. Enquanto entre os anos 70 e 1993 abarca o processo de modernização da agropecuária brasileira, que serviu de base para a criação de um complexo agroindustrial no país, já incluindo um aumento nas exportaçóes do setor. Por fim, no pós 93 até o início dos anos 2000, verifica-se um aumento da produção, mas dessa vez voltada para as exportaçóes.

De modo geral, no período como um todo (1930-2000), verifica-se um processo de redução significativa da participação dos produtos primários na pauta de exportação brasileira, embora, de acordo com dados do Ministério da Agricultura, Pecuária e Abastecimento (MAPA) (2018), essa participação é em média três vezes maior, do que na pauta de exportaçáo mundial. Ou seja, embora em proporçáo menor, quando comparada a períodos anteriores, o setor agrícola ainda possui importância relativa para a economia brasileira, especialmente no comércio exterior. A seção seguinte, tem como objetivo, apresentar um panorama do setor externo brasileiro nos primeiros anos do século XXI(2001 a 2016), através de variáveis selecionadas, mostrando a evolução do mesmo, bem como suas características e determinantes. 


\section{BREVE ANÁLISE DO SETOR EXTERNO DA ECONOMIA BRASILEIRA ENTRE 2001 E 2016}

\subsection{Balança comercial}

A balança comercial se trata da relação entre as importaçóes e exportaçóes, a mesma se configura como uma variável que ajuda na compreensão do intercâmbio comercial de uma nação. É possível verificar no Gráfico 1, a evolução das dos fluxos de importação e exportação como também o saldo comercial.

Gráfico 1 - Evolução da balança comercial brasileira (Em bilhões de US\$) 2001 - 2016

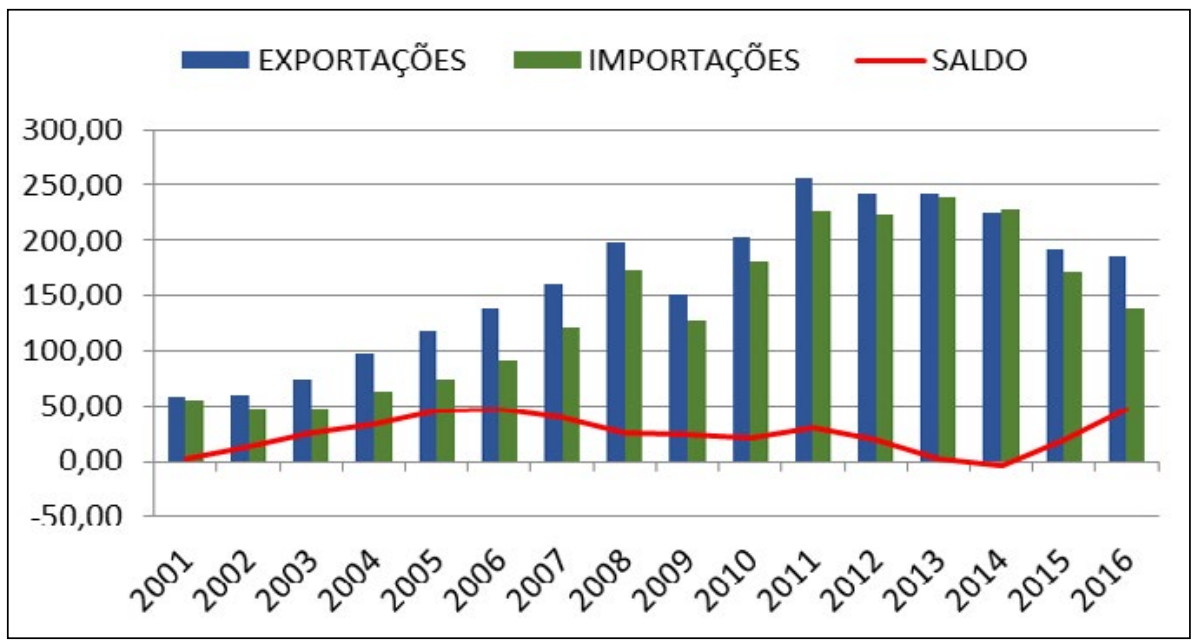

Fonte: Elaboração própria com base em dados do Brasil e do MDIC (2017)

É importante ressaltar que, a partir de 2001, tanto as importaçóes quanto as exportaçóes subiram significativamente, esse aumento dos fluxos de comércio do Brasil com os demais países ocorre por conta de uma série de fatores estruturais e conjunturais como: efeitos remanescentes do processo de abertura comercial iniciado ainda na década de 90, o processo de desburocratização das exportaçóes iniciado em 2004, o chamado "boom" das Commodities, além da intensificação do processo de industrialização da economia chinesa (BANCO CENTRAL DO BRASIL, 2003).

Nota-se também que, em grande parte do período analisado, o saldo da balança comercial é positivo, com exceção do ano de 2014, onde houve um déficit de quase quatro bilhóes de dólares (pior resultado desde 1999). Esse déficit foi resultado de uma série de fatores como: a crise política e econômica da Argentina, a queda dos preços das commodities (Gráfico 2), em especial do minério de ferro e o aumento na importação de combustíveis (GODINHO, 2015).

A composição das pautas de importação e exportação podem ser observadas no Gráfico 2. De modo geral, verifica-se que a uma grande disparidade entre as pautas de importaçáo e exportação brasileira. Enquanto a maior parte das exportações é composta por produtos 
básicos, os produtos manufaturados ocupam uma parcela extremamente significativa das importaçóes locais. É possível notar também que, apesar de ambas as pautas apresentarem uma certa concentração em determinados tipos de produtos, essa concentração é ainda maior no caso das importaçôes.

Gráfico 2 - Balança comercial brasileira por fator agregado 2001 - 2016

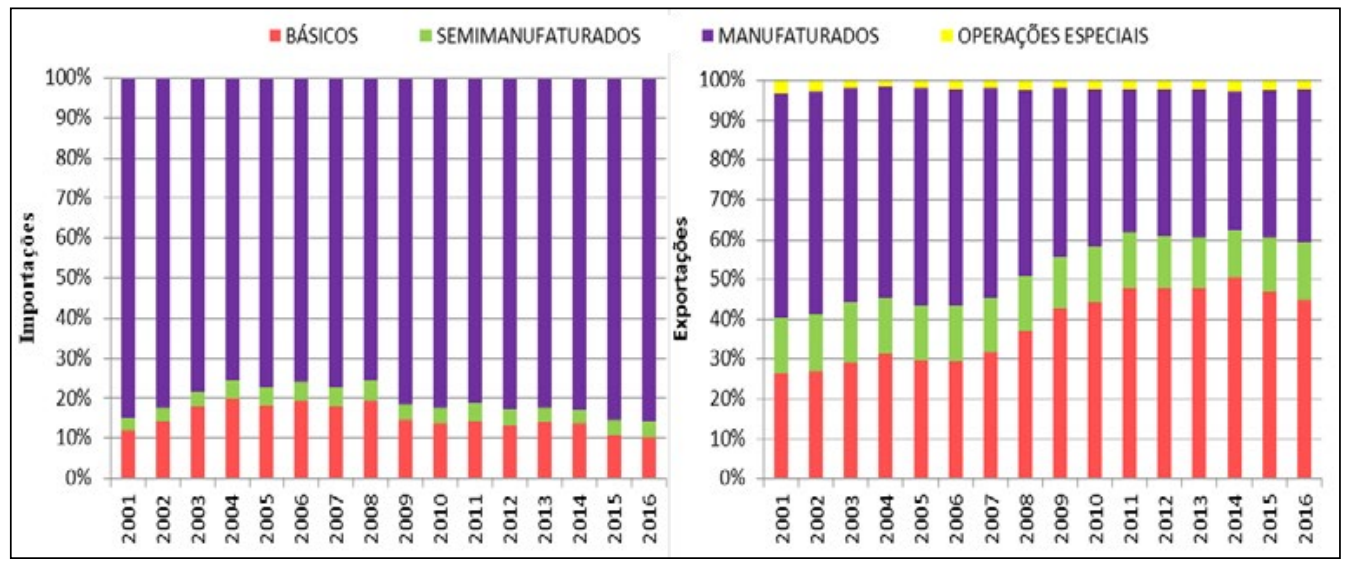

Fonte: Elaboração própria com base em dados do MDIC (2017)

Quanto ao comportamento ao longo do tempo, tem-se que, a pauta de importaçóes é majoritariamente ocupada por produtos manufaturados, onde, verifica-se um processo de redução dessa situação entre os anos de 2001 e 2008, porém, tal processo se reverte, a partir de 2009, de modo que, a participaçáo desses produtos no ano de 2016 é superior a registrada no início da série. Quanto às exportaçôes, o caminho é o inverso. Entre 2001 e 2007, os produtos manufaturados e semimanufaturados abarcam boa parte da pauta, porém de 2008 em diante, a participação desses produtos cai, em detrimento dos produtos básicos.

\subsection{Preço das commodities}

As commodities são historicamente produtos de extrema importância para a economia brasileira, desse modo, os preços desses produtos se tornam uma variável que possui um peso bastante significativo sobre a balança comercial e consequentemente sobre o PIB nacional. Através do Gráfico 3, pode-se observar o comportamento dos preços desses produtos.

Os preços das commodities voltam a cair a partir de 2008, com a deflagração da crise financeira mundial. Os efeitos sobre a economia brasileira foram diversos neste período. Pelo lado positivo houve uma melhora nos termos de troca, tendo em vista que os principais produtos exportados pelo país, como a soja, os minérios de ferro, o café, dentre outros experimentaram um período duradouro de elevação dos preços. 
Gráfico 3 - Evolução do índice de preço das Commodities (ICI) 2001-2016

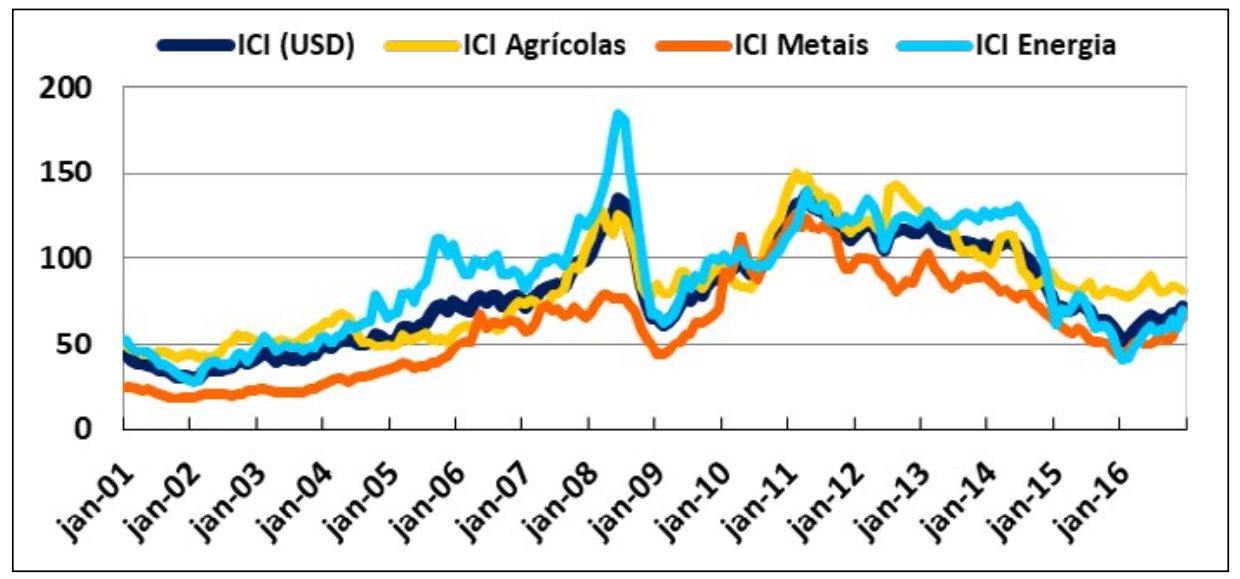

Fonte: Itaú (2017)

Pelo lado negativo os recursos advindos deste ciclo de alta tiveram um efeito de sobrevalorização artificial da moeda nacional, afetando negativamente os setores industriais com o escoamento de investimentos para estas commodities, que se mostravam mais rentáveis naquele momento, e com o "encarecimento" de insumos importados, apresentando os típicos sintomas da chamada "Doença Holandesa”. Entre 2012 e 2014, os preços se estabilizam e voltam a cair em 2015. (BRESSER-PEREIRA; MARCONI, 2008).

\subsection{Participaçáo no comércio exterior}

A economia brasileira é considerada uma economia relativamente fechada, especialmente quando comparada com os países desenvolvidos. $\mathrm{O}$ processo de abertura comercial da década de 90 tornou a economia mais livre e com uma maior participação do setor externo, elevando significativamente os níveis de importação, assim como os fluxos de exportação (PEREIRA, 2017). O Gráfico 4 representa a participação das importaçóes e exportações brasileiras nas importações e exportações mundiais.

A partir de 2003 é possível visualizar um aumento da participação do país no comércio exterior, refletindo uma série de fatores como o estreitamento do comércio bilateral com a economia chinesa, o aumento dos preços das commodities, o processo de desburocratizaçáo das exportaçóes, tendência de apreciação da taxa de câmbio e aumento da renda do PIB, que em alguns momentos deste período cresce a taxa superior ao crescimento da economia mundial (CANCO CENTRAL DO BRASIL, 2003).

Em 2008, com a deflagração da crise financeira internacional. Variáveis como a renda do mundo e preço das commodities, que possuem um efeito significativo sobre as exportaçóes domésticas foram afetadas, causando uma contração da economia mundial e uma interrupção no processo de alta dos preços das commodities, contribuindo com a interrupção do ritmo de crescimento da participação das exportaçóes brasileiras nas exportaçóes mundiais. 
Após 2009, percebe-se uma recuperação da participação das importações, quanto uma retomada do crescimento da participação das exportaçóes, como consequência de políticas expansionistas adotadas com o intuito de reduzir os efeitos da crise. Quanto às exportaçóes, verifica-se em 2009 um período a retomada do ciclo da elevação dos preços das commodities possibilitando um aumento do fluxo das exportaçóes brasileiras.

Gráfico 4 - Participação das importações e exportações brasileiras nas importações e exportaçóes mundiais 2001-2016

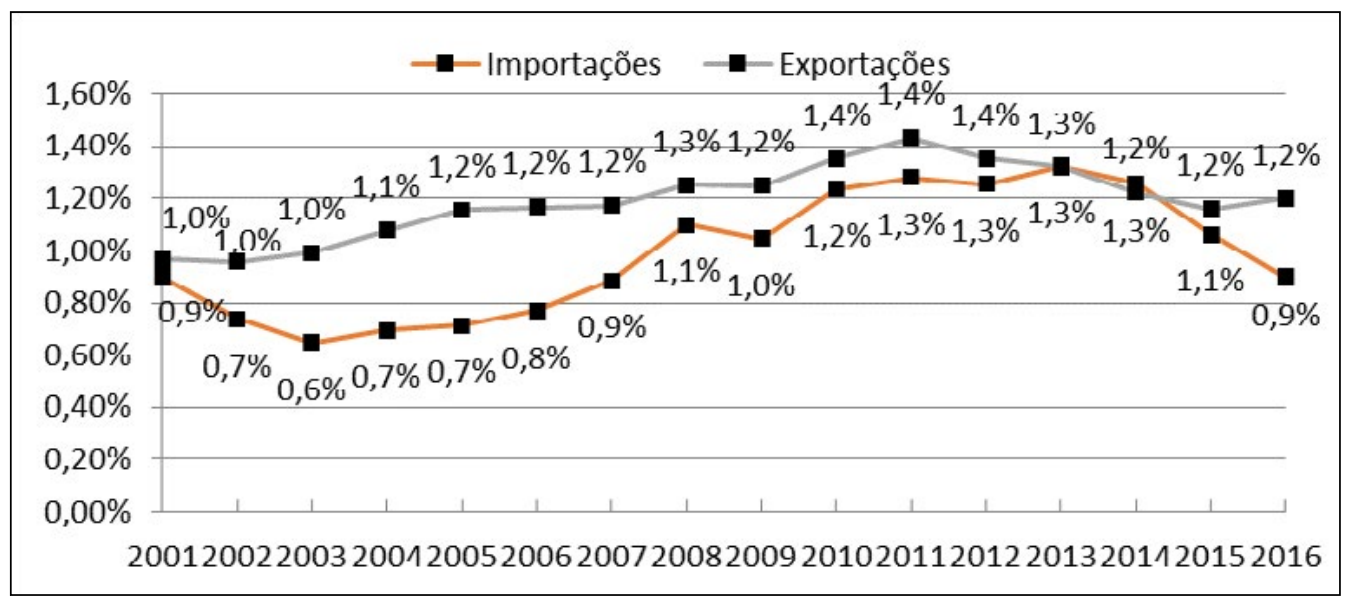

Fonte: Elaboração própria com base em dados do MDIC (2017)

Tantos os fatores que possibilitaram o aumento da participação das importaçóes, quanto os que possibilitam o aumento da participação das exportaçóes tiveram efeitos significativos até meados de 2013. Tendo em vista que em 2014, além do cenário externo se encontrar menos favorável à economia brasileira, especialmente pelo início de um ciclo de queda dos preços das commodities, tem-se um período bem particular para o país, iniciado com o desfecho das eleiçóes presidenciais de 2014 e abarcando a instauração de uma crise política e econômica.

\section{PROCEDIMENTOS METODOLÓGICOS}

Quanto aos objetivos, esta pesquisa pode ser considerada exploratória, por proporcionar maior familiaridade com o tema. Explicativa, por tentar identificar os fatores que afetam o comportamento do fenômeno analisado. E descritiva por possibilitar a descriçáo e avaliaçáo dos resultados obtidos. Quanto aos procedimentos metodológicos caracteriza-se como uma pesquisa bibliográfica, por utilizar dados secundários, do World Bank, UNCOMTRADE, Trademap, Banco Central do Brasil, IPEADATA, dentre outros, além de livros e periódicos (GIL, 2002).

A nomenclatura utilizada para os produtos foi a Standart International Trade Classification (SITC), Rev. 2, adotada pela United Nations Conference on Trade and Development - UNCTAD ao nível de 3 dígitos desagregação. E para classificar estes produtos 
de acordo com a sua intensidade tecnológica, adotou-se a classificação setorial proposta por Lall (2000). O modo como os produtos são classificados podem ser vistos no Quadro 1.

Quadro 1 - Classificação setorial segundo Lall (2000)

\begin{tabular}{|c|}
\hline 1 - Produtos Primários (PP) \\
2 - Baseados em recursos naturais \\
2.1 - Agro-Baseados (RB1) \\
2.2 - Outros (RB2) \\
3 - Manufaturas de baixa tecnologia \\
3.1 - Têxtil, vestuário e calçados (LT1). \\
3.2 - Outros produtos (LT2) \\
4 - Manufaturas de média tecnologia \\
4.1 - Automotivo (MT1) \\
4.2 - Processo (MT2) \\
4.3 - Engenharia (MT3) \\
5 - Manufaturas de alta tecnologia \\
5.1 - Eletrônicos e elétricos (AT1) \\
5.2 - Outros (AT2)
\end{tabular}

Fonte: Schmidt Filho e Lima (2012)

De acordo com Amaral, Freitas e Castilho (2016, p. 10) pode-se dizer que os produtos primários representam produtos agrícolas que possuem pouco ou não possui nenhum tipo de tratamento, onde as exportaçóes são basicamente in natura, enquanto os produtos baseados em recursos naturais são também produtos com baixo grau de processamento, intensivo em trabalho, como o setor de alimentos processados e o refino de petróleo.

Manufaturas de baixa tecnologia representam produtos com pouco dinamismo e baixa elasticidade renda como manufaturas têxteis, de calçados e de plástico. Manufaturas de média tecnologia são manufaturas com alto grau de P\&D e compreende bens intermediários e bens de capital e abrange setores como o setor automobilístico, o setor de autopeças, dentre outros.

Enquanto o setor de alta tecnologia é um setor que emprega tecnologias avançadas tendo como exemplo os setores de eletrônicos e setores aeroespaciais. A delimitaçâo deste trabalho abrange todo o setor de produtos primários (PP) de acordo com a classificação de Lall (2000). A descrição de cada produto, juntamente com a o seu código de SITC (Classificação baseada no Sistema Harmonizado de Designação e de Codificação de Mercadorias) podem ser conferidos no Quadro 3.

Para consolidar as informaçóes da pesquisa bibliográfica serão utilizados nesta pesquisa, indicadores de comércio internacional, que serão: Índice de Vantagens Comparativas Reveladas (IVCR), Índice de Contribuição ao Saldo (CS) e o Market Share (MS). Os escolhidos fazem parte da categoria Produtos Primários (PP). Os indicadores serão calculados com o objetivo de possibilitar uma análise setorial do Brasil com o mundo. 
Quadro 3 - SITC e descrição dos Produtos que compóe o grupo Produtos Primários (PP)

\begin{tabular}{|c|c|c|c|}
\hline SITC & PRODUTO & SITC & PRODUTO \\
\hline 001 & $\begin{array}{c}\text { Animais vivos (principalmente para } \\
\text { alimentação) }\end{array}$ & 232 & Látex de borracha natural \\
\hline 011 & Carnes e miudezas comestíveis & 244 & Cortiça (madeira) \\
\hline 022 & Leite e creme & 245 & Combustíveis de madeira \\
\hline 025 & Ovos de pássaros & 246 & Polpa (madeira) \\
\hline 034 & Peixe fresco & 261 & Seda \\
\hline 036 & Crustáceos e moluscos & 263 & Algodão \\
\hline 041 & Trigo & 268 & Lã e pelos de animais \\
\hline 042 & Arroz & 271 & Fertilizantes \\
\hline 043 & Cevada & 273 & Pedra, areia, cascalho. \\
\hline 044 & Milho & 274 & Poleias de ferro \\
\hline 045 & Cereais & 277 & Abrasivos naturais \\
\hline 054 & Produtos hortícolas & 278 & Outros minerais brutos \\
\hline 057 & Frutas e nozes & 291 & Materiais de animais brutos \\
\hline 071 & Café & 292 & Materiais de vegetais brutos \\
\hline 072 & Cacau & 322 & Carvão linhita e turfa \\
\hline 074 & Chá e mate & 333 & $\begin{array}{c}\text { Petróleo bruto e óleo de minerais } \\
\text { betuminosos }\end{array}$ \\
\hline 075 & Especiarias & 341 & Gás natural manufaturado \\
\hline 081 & Material para alimentação de animais & 681 & Prata, platina e outros metais. \\
\hline 091 & Margarina & 682 & Cobre \\
\hline 121 & Tabaco manufaturado & 683 & Níquel \\
\hline 211 & Couro cru e peles & 684 & Alumínio \\
\hline 212 & Peles com pelo & 685 & Chumbo \\
\hline 222 & Sementes e frutos oleaginosos & 686 & Zinco \\
\hline 223 & $\begin{array}{l}\text { Sementes e frutos oleaginosos (incluindo } \\
\text { farinhas e refeiçóes) }\end{array}$ & 687 & Estranho \\
\hline
\end{tabular}

Fonte: Adaptado. UNCOMTRADE (2017)

Será utilizada a base de dados das Naçóes Unidas UNCOMTRADE para as exportaçōes e importaçóes (nacionais e mundiais) setoriais, do Trademap para as exportaçóes e importações totais (nacionais e mundiais), e os dados referentes ao PIB brasileiro e mundial selecionados serão retirados da base de dados do World Bank.

\subsection{Indicadores de comércio internacional}

O Market Share tem como objetivo, verificar o percentual a participação das exportaçóes em um determinado país ou bloco comercial. Neste trabalho pretendese verificar o Market Share do Brasil em relação ao mundo, a fórmula para o cálculo do indicador está descrita abaixo: 


$$
\mathrm{MS}=\frac{\mathrm{Xij}_{\mathrm{j}}}{\mathrm{X}_{\mathrm{j}}}
$$

O MS representa a participação em termos percentuais em determinado mercado. Para atender aos critérios propostos ao indicador neste trabalho o MS deve ser maior que a participação brasileira no mercado externo como um todo. Ou seja, o setor em questáo tem que estar acima da média do agregado dos demais setores.

O IVCR de Balassa (1965) se baseia na lei das vantagens comparativas formulada por David Ricardo (1817) e mede a intensidade da especialização do comércio internacional de um país relativamente a uma região ou ao mundo e pode ser descrito através da fórmula abaixo:

$$
\mathrm{VCR}=\frac{\mathrm{x}_{\mathrm{ij}} / \mathrm{x}_{\mathrm{j}}}{\mathrm{x}_{\mathrm{i}} / \mathrm{x}}
$$

O Índice de Contribuição ao Saldo (CS) utiliza dados referentes às importações e exportaçóes, além do PIB, com o objetivo de mostrar a real contribuição do setor para a balança comercial do país ou grupo comercial.

$$
C S=\left(\frac{1000}{P I B_{j}}\right) *\left\{\left(X_{j}-M_{j}\right)-\left[\frac{\left(X_{j}+M_{j}\right)}{\left(X_{j}+M_{j}\right) *\left(X_{j}-M_{j}\right)}\right]\right\}
$$

Onde:

$\mathrm{X}_{\mathrm{ij}}=$ exportaçóes do grupo setorial i pelo país $\mathrm{j} ; \mathrm{X}_{\mathrm{j}}=$ exportaçóes totais realizadas pelo país $\mathrm{j}$; $\mathrm{X}_{\mathrm{i}}=$ exportaçóes do grupo setorial $\mathrm{i}$ no mundo; $\mathrm{X}=$ exportações mundiais totais; $\mathrm{M}_{\mathrm{ij}}=$ importaçóes do grupo setorial i pelo país j; $M_{j}=$ importaçóes totais realizadas pelo país j e $\mathrm{PIB}_{\mathrm{j}}=$ Produto Interno Bruto do país $\mathrm{j}$.

Os resultados críticos, bem como as conclusóes do indicador estão contidos no Quadro 3.

Quadro 3 - Indicadores de comercio internacional: IVCR e CS

\begin{tabular}{cc}
\hline Indicador & Conclusáo \\
\hline & IVCR \\
\hline $0<$ IVCR $\leq 1$ & O produto não possui vantagem comparativa revelada; \\
$1<\mathrm{IVCR} \leq 2$ & O produto possui vantagem comparativa revelada fraca; \\
$2<\mathrm{IVCR} \leq 4$ & O produto possui vantagem comparativa revelada média; \\
$4<\mathrm{IVCR}$ & O produto possui vantagem comparativa revelada forte. \\
\hline & CS \\
\hline $\mathrm{CS}>0$ & Contribuição ao saldo Positiva; \\
$\mathrm{CS}<0$ & Contribuição ao saldo Negativa; \\
$\mathrm{CS}=0$ & Contribuição nula. \\
\hline
\end{tabular}

Fonte: Hinloopen e Marrewijk (2001) 


\section{ANÁLISE DA COMPETITIVIDADE DO SETOR PRIMÁRIO BRASILEIRO NO SÉCULO XXI POR MEIO DE INDICADORES DE COMÉRCIO EXTERIOR}

Através da Tabela 1 pode-se visualizar os resultados para o indicador Market Share, ou seja, o percentual de mercado de um grupo setorial que é suprido pelas exportaçóes brasileiras. A região sombreada cinza compreende produtos que possuem um Market Share superior ao das exportaçóes globais. Ou seja, quando determinados setores abarcam uma parcela do mercado superior a participação das exportaçôes brasileiras nas exportaçóes mundiais (Gráfico 4).

Os produtos que mais se destacam foram: carnes e miudezas (SITC 011), café (SITC 071), tabaco manufaturado (SITC 121) e sementes e frutos oleaginosos (SITC 222) mantêm uma média de participação em um patamar acima de dois dígitos. O produto sementes e frutos oleaginosos é o produto que obtém os resultados mais expressivos, de modo que, em média apresenta um $M S$ próximo dos $25 \%$, ou em outras palavras, quase um quarto das importaçōes pelo produto é suprida pelas exportaçōes brasileiras.

Ao desagregar o produto sementes e frutos oleaginosos é possível encontrar de forma mais explícita, produtos que, conhecidamente possuem um grande peso sobre a balança comercial brasileiro como a soja e a semente de algodáo, o que de certa forma corrobora o grau o resultado expressivo que o setor obteve. Os demais produtos que obtiveram destaque foram o café, produto que historicamente é uma das principais fontes de divisas externas para a economia brasileira, assim como o tabaco e o complexo das carnes.

Vale destacar que existe certo grau de concentração dentro do comércio de produtos primários, que por si só já concentram a pauta de exportaçôes do país. É possível observar que os produtos que obtiveram as maiores fatias do mercado mundial estáo associados a produtos com menos tratamento, ou, o mais próximos possíveis de produtos in natura, constituídos por alimentos e insumos agrícolas, enquanto produtos que precisam de um processo mais sofisticado para a extração e consequentemente possuem preços mais elevados, como os minérios, ainda ocupam uma parcelas mais modestas do mercado mundial. 


\begin{tabular}{|c|c|c|c|c|c|c|c|c|c|c|c|c|c|c|c|c|c|}
\hline SITC & PRODUTO & 2001 & 2002 & 2003 & 2004 & 2005 & 2006 & 2007 & 2008 & 2009 & 2010 & 2011 & 2012 & 2013 & 2014 & 2015 & 2016 \\
\hline 001 & Animais vivos & 0,05 & 0,05 & 0,11 & 0,16 & 0,35 & 0,64 & 1,91 & 2,51 & 2,93 & 4,12 & 2,55 & 3,15 & 3,80 & 3,41 & 1,46 & 1,53 \\
\hline 011 & Carnes e miudezas comestíveis & 6,56 & 7,05 & 8,05 & 10,49 & 11,79 & 11,42 & 12,43 & 12,65 & 11,32 & 12,40 & 11,87 & 11,89 & 12,13 & 11,91 & 11,67 & 11,36 \\
\hline 022 & Leite e creme & 0,11 & 0,27 & 0,26 & 0,43 & 0,48 & 0,53 & 0,81 & 1,40 & 0,49 & 0,31 & 0,19 & 0,20 & 0,17 & 0,63 & 0,87 & 0,45 \\
\hline 025 & Ovos de pássaros & 1,13 & 0,68 & 0,61 & 1,02 & 1,46 & 1,24 & 1,68 & 2,46 & 1,95 & 2,59 & 2,38 & 1,95 & 1,16 & 1,59 & 1,51 & 1,22 \\
\hline 034 & Peixe fresco & 0,36 & 0,36 & 0,36 & 0,35 & 0,33 & 0,29 & 0,27 & 0,19 & 0,18 & 0,19 & 0,19 & 0,20 & 0,17 & 0,15 & 0,20 & 0,22 \\
\hline 036 & Crustáceos e moluscos & 1,17 & 1,53 & 1,77 & 1,66 & 1,45 & 1,19 & 0,80 & 0,68 & 0,41 & 0,41 & 0,28 & 0,19 & 0,23 & 0,19 & 0,21 & 0,18 \\
\hline 041 & Trigo & 0,00 & 0,00 & 0,05 & 1,06 & 0,08 & 0,31 & 0,10 & 0,46 & 0,20 & 0,69 & 1,47 & 1,22 & 0,71 & 0,21 & 0,91 & 0,32 \\
\hline 042 & Arroz & 0,08 & 0,09 & 0,07 & 0,09 & 0,57 & 0,57 & 0,40 & 1,48 & 1,41 & 0,80 & 2,54 & 2,27 & 1,56 & 1,50 & 1,51 & 1,21 \\
\hline 043 & Cevada & 0,28 & 0,00 & 0,00 & 0,00 & 0,00 & 0,00 & 0,00 & 0,09 & 0,00 & 0,00 & 0,00 & 0,00 & 0,08 & 0,00 & 0,05 & 0,00 \\
\hline 044 & Milho & 5,60 & 2,69 & 3,41 & 5,12 & 1,07 & 3,65 & 9,36 & 5,19 & 6,58 & 9,50 & 8,02 & 15,03 & 17,85 & 11,87 & 17,45 & 12,84 \\
\hline 045 & Cereais & 0,02 & 0,07 & 1,98 & 0,96 & 0,21 & 0,10 & 1,49 & 0,09 & 0,12 & 0,06 & 0,14 & 0,10 & 0,13 & 0,19 & 0,16 & 0,07 \\
\hline 054 & Produtos hortícolas & 0,06 & 0,07 & 0,04 & 0,04 & 0,04 & 0,04 & 0,11 & 0,04 & 0,07 & 0,03 & 0,06 & 0,07 & 0,05 & 0,09 & 0,13 & 0,08 \\
\hline 057 & Frutas e nozes & 1,24 & 1,23 & 1,40 & 1,47 & 1,44 & 1,39 & 1,60 & 1,46 & 1,29 & 1,20 & 1,08 & 1,02 & 0,88 & 0,78 & 0,86 & 0,75 \\
\hline 071 & Café & 16,35 & 16,28 & 15,75 & 17,59 & 19,02 & 18,58 & 17,81 & 18,27 & 17,68 & 19,83 & 20,64 & 16,28 & 15,23 & 17,19 & 16,68 & 14,88 \\
\hline 072 & Cacau & 2,23 & 2,28 & 2,79 & 2,37 & 2,85 & 2,52 & 2,32 & 2,09 & 1,53 & 1,71 & 1,49 & 1,34 & 1,13 & 1,25 & 1,61 & 1,52 \\
\hline 074 & Chá e mate & 1,15 & 1,04 & 0,73 & 0,70 & 0,86 & 0,92 & 0,94 & 0,95 & 0,91 & 0,95 & 1,21 & 1,31 & 1,31 & 1,80 & 1,76 & 1,41 \\
\hline 075 & Especiarias & 3,51 & 3,56 & 2,99 & 3,51 & 3,62 & 3,98 & 3,73 & 3,07 & 2,94 & 2,25 & 2,85 & 2,75 & 3,12 & 3,80 & 3,83 & 2,79 \\
\hline 081 & Material para alimentação de animais & 9,87 & 10,00 & 10,60 & 11,47 & 9,96 & 7,82 & 7,70 & 8,58 & 9,22 & 8,72 & 8,93 & 9,11 & 8,55 & 8,67 & 8,34 & 7,80 \\
\hline 091 & Margarina & 0,33 & 0,22 & 0,35 & 0,99 & 0,65 & 0,47 & 0,60 & 0,79 & 0,73 & 0,85 & 0,94 & 0,47 & 0,68 & 1,25 & 0,92 & 0,49 \\
\hline 121 & Tabaco manufaturado & 15,86 & 18,47 & 18,97 & 20,51 & 23,92 & 22,78 & 25,70 & 26,74 & 26,72 & 25,21 & 25,59 & 25,97 & 24,88 & 20,40 & 19,27 & 18,45 \\
\hline 211 & Couro cru e peles & 0,15 & 0,15 & 0,09 & 0,05 & 0,12 & 0,11 & 0,14 & 0,22 & 0,20 & 0,16 & 0,03 & 0,10 & 0,20 & 0,13 & 0,12 & 0,09 \\
\hline 212 & Peles com pelo & 0,00 & 0,00 & 0,00 & 0,00 & 0,01 & 0,01 & 0,02 & 0,03 & 0,02 & 0,02 & 0,02 & 0,02 & 0,00 & 0,00 & 0,00 & 0,00 \\
\hline 222 & Sementes e frutos oleaginosos & 18,94 & 20,47 & 21,25 & 25,59 & 25,41 & 25,32 & 21,17 & 22,08 & 25,28 & 20,52 & 25,18 & 23,22 & 28,56 & 29,35 & 30,84 & 28,02 \\
\hline 223 & Sementes e frutos oleaginosos (comestíveis) & 0,09 & 0,08 & 0,05 & 0,04 & 0,07 & 0,07 & 0,10 & 0,03 & 0,02 & 0,03 & 0,01 & 0,01 & 0,00 & 0,02 & 0,02 & 0,02 \\
\hline 232 & Látex de borracha natural & 0,00 & 0,01 & 0,01 & 0,01 & 0,00 & 0,00 & 0,02 & 0,01 & 0,03 & 0,12 & 0,12 & 0,14 & 0,03 & 0,02 & 0,05 & 0,03 \\
\hline 244 & Cortiça (madeira) & 0,01 & 0,01 & 0,00 & 0,00 & 0,01 & 0,01 & 0,00 & 0,01 & 0,00 & 0,00 & 0,00 & 0,00 & 0,00 & 0,00 & 0,00 & 0,00 \\
\hline 245 & Combustíveis de madeira & 0,83 & 0,70 & 0,59 & 1,16 & 0,76 & 0,51 & 0,49 & 0,21 & 0,25 & 0,12 & 0,05 & 0,04 & 0,05 & 0,05 & 0,12 & 0,11 \\
\hline 246 & Polpa (madeira) & 2,75 & 2,94 & 2,97 & 3,47 & 3,52 & 3,37 & 2,97 & 3,00 & 2,23 & 2,10 & 1,74 & 1,92 & 1,84 & 1,78 & 1,93 & 2,08 \\
\hline 261 & Seda & 0,61 & 0,79 & 0,78 & 0,58 & 0,64 & 0,39 & 0,31 & 0,24 & 0,18 & 0,23 & 0,15 & 0,10 & 0,17 & 0,14 & 0,16 & 0,24 \\
\hline 263 & Algodão & 2,50 & 1,59 & 2,36 & 3,95 & 5,14 & 3,64 & 4,91 & 6,56 & 8,30 & 5,68 & 7,63 & 10,43 & 6,06 & 9,44 & 11,99 & 11,29 \\
\hline 268 & Lã e pelos de animais & 0,18 & 0,19 & 0,24 & 0,18 & 0,19 & 0,22 & 0,22 & 0,27 & 0,58 & 0,49 & 0,40 & 0,54 & 0,65 & 0,62 & 0,67 & 0,55 \\
\hline 271 & Fertilizantes & 0,03 & 0,04 & 0,10 & 0,10 & 0,07 & 0,07 & 0,09 & 0,03 & 0,05 & 0,11 & 0,14 & 0,20 & 0,19 & 0,20 & 0,15 & 0,14 \\
\hline 273 & Pedra, areia, cascalho. & 1,12 & 1,22 & 2,50 & 2,38 & 2,75 & 2,83 & 2,43 & 1,87 & 1,76 & 2,68 & 2,61 & 2,48 & 2,71 & 2,36 & 2,15 & 2,21 \\
\hline 274 & Poleias de ferro & 0,02 & 0,04 & 0,02 & 0,02 & 0,08 & 0,03 & 0,02 & 0,01 & 0,03 & 0,02 & 0,01 & 0,02 & 0,06 & 0,06 & 0,09 & 0,11 \\
\hline 277 & Abrasivos naturais & 0,03 & 0,04 & 0,44 & 0,67 & 0,33 & 0,03 & 0,03 & 0,06 & 0,03 & 0,05 & 0,04 & 0,04 & 0,04 & 0,07 & 0,05 & 0,10 \\
\hline 278 & Outros minerais brutos & 3,21 & 3,24 & 3,40 & 3,32 & 3,25 & 3,46 & 3,66 & 3,68 & 3,87 & 3,26 & 3,07 & 3,09 & 2,90 & 2,85 & 3,08 & 3,02 \\
\hline 291 & Materiais de animais brutos & 2,49 & 2,70 & 3,25 & 3,20 & 3,41 & 3,56 & 4,66 & 5,29 & 6,06 & 6,42 & 5,87 & 6,19 & 6,15 & 6,08 & 5,11 & 4,96 \\
\hline 292 & Materiais de vegetais brutos & 0,49 & 0,49 & 0,51 & 0,49 & 0,52 & 0,57 & 0,61 & 0,64 & 0,59 & 0,63 & 0,67 & 0,68 & 0,57 & 0,61 & 0,56 & 0,62 \\
\hline 322 & Carvão linhita e turfa & 0,00 & 0,00 & 0,00 & 0,00 & 0,00 & 0,00 & 0,00 & 0,00 & 0,00 & 0,00 & 0,01 & 0,00 & 0,00 & 0,00 & 0,00 & 0,00 \\
\hline 333 & Petróleo bruto e óleo de minerais betuminosos & 0,23 & 0,53 & 0,56 & 0,53 & 0,67 & 0,80 & 0,98 & 1,05 & 1,17 & 1,47 & 1,41 & 1,41 & 0,86 & 1,26 & 1,85 & 1,74 \\
\hline 341 & Gás natural manufaturado & 0,00 & 0,02 & 0,03 & 0,01 & 0,03 & 0,01 & 0,01 & 0,00 & 0,00 & 0,00 & 0,01 & 0,04 & 0,02 & 0,01 & 0,01 & 0,05 \\
\hline 681 & Prata, platina e outros metais. & 0,11 & 0,26 & 0,25 & 0,11 & 0,13 & 0,19 & 0,07 & 0,07 & 0,07 & 0,07 & 0,08 & 0,10 & 0,06 & 0,09 & 0,06 & 0,08 \\
\hline 682 & Cobre & 0,37 & 0,58 & 0,45 & 0,53 & 0,66 & 0,80 & 0,84 & 0,83 & 0,68 & 0,47 & 0,59 & 0,38 & 0,75 & 0,54 & 0,91 & 0,97 \\
\hline 683 & Níquel & 0,95 & 1,07 & 1,28 & 1,44 & 1,37 & 1,08 & 1,25 & 1,17 & 1,16 & 1,22 & 1,53 & 1,45 & 1,38 & 1,19 & 1,30 & 0,68 \\
\hline 684 & Alumínio & 2,34 & 2,55 & 2,64 & 2,69 & 2,45 & 2,72 & 2,59 & 2,26 & 2,11 & 1,63 & 1,37 & 1,22 & 1,01 & 0,87 & 0,80 & 0,77 \\
\hline 685 & Chumbo & 0,01 & 0,01 & 0,01 & 0,01 & 0,01 & 0,00 & 0,06 & 0,01 & 0,00 & 0,01 & 0,01 & 0,04 & 0,02 & 0,00 & 0,02 & 0,35 \\
\hline 686 & Zinco & 0,49 & 1,10 & 1,17 & 1,07 & 1,42 & 1,38 & 0,92 & 0,86 & 1,24 & 1,22 & 1,37 & 0,93 & 0,49 & 0,41 & 0,96 & 1,34 \\
\hline 687 & Estranho & 1,98 & 1,71 & 1,12 & 1,57 & 1,34 & 1,21 & 1,75 & 1,83 & 1,27 & 0,48 & 1,17 & 1,90 & 2,02 & 2,59 & 2,91 & 3,04 \\
\hline
\end{tabular}

Fonte: Elaboração própria com base em dados do UNCOMTRADE e do Trademap (2017)

Esta comparação entre a participação das exportaçóes totais e das exportaçôes setoriais é importante, tendo em vista que, se os produtos primários representam os principais produtos que compóe a pauta de exportaçóes brasileiras, quanto maior for o alcance desses produtos, melhor será o efeito nas contas externas do país.

Em termos de competitividade, é possível visualizar na Tabela 2 aqueles produtos que se mostraram competitivos no comércio internacional (são os que se encontram sombreados em cinza). Os produtos que obtiveram os melhores resultados foram: sementes e frutos oleaginosos (SITC 222), tabaco manufaturado (SITC 121), café (71) e material para a alimentação de animais (81) que são os únicos produtos que apresentam um indicador no patamar de dois dígitos. 


\begin{tabular}{|c|c|c|c|c|c|c|c|c|c|c|c|c|c|c|c|c|c|}
\hline SITC & PRODUTO & 2001 & 2002 & 2003 & 2004 & 2005 & 2006 & 2007 & 2008 & 2009 & 2010 & 2011 & 2012 & 2013 & 2014 & 2015 & 2016 \\
\hline 001 & Animais vivos & 0,06 & 0,05 & 0,11 & 0,15 & 0,30 & 0,56 & 1,65 & 2,02 & 2,37 & 3,08 & 1,80 & 2,39 & 2,96 & 2,86 & 1,26 & 1,32 \\
\hline 011 & Carnes e miudezas comestíveis & 6,90 & 7,49 & 8,24 & 9,87 & 10,29 & 9,91 & 10,70 & 10,21 & 9,14 & 9,27 & 8,39 & 9,01 & 9,46 & 10,00 & 10,03 & 9,75 \\
\hline 022 & Leite e creme & 0,11 & 0,29 & 0,26 & 0,40 & 0,42 & 0,46 & 0,69 & 1,13 & 0,39 & 0,23 & 0,14 & 0,15 & 0,13 & 0,53 & 0,75 & 0,39 \\
\hline 025 & Ovos de pássaros & 1,18 & 0,72 & 0,63 & 0,96 & 1,27 & 1,08 & 1,45 & 1,99 & 1,57 & 1,94 & 1,68 & 1,48 & 0,91 & 1,34 & 1,30 & 1,04 \\
\hline 034 & Peixe fresco & 0,37 & 0,38 & 0,37 & 0,33 & 0,29 & 0,25 & 0,24 & 0,16 & 0,15 & 0,14 & 0,14 & 0,15 & 0,13 & 0,13 & 0,17 & 0,19 \\
\hline 036 & Crustáceos e moluscos & 1,23 & 1,63 & 1,81 & 1,56 & 1,27 & 1,03 & 0,69 & 0,55 & 0,33 & 0,30 & 0,20 & 0,15 & 0,18 & 0,16 & 0,18 & 0,16 \\
\hline 041 & Trigo & 0,00 & 0,00 & 0,05 & 0,99 & 0,07 & 0,27 & 0,08 & 0,37 & 0,16 & 0,52 & 1,04 & 0,93 & 0,55 & 0,18 & 0,78 & 0,27 \\
\hline 042 & Arroz & 0,09 & 0,10 & 0,07 & 0,08 & 0,49 & 0,49 & 0,35 & 1,19 & 1,14 & 0,60 & 1,79 & 1,72 & 1,22 & 1,26 & 1,30 & 1,04 \\
\hline 043 & Cevada & 0,29 & 0,00 & 0,00 & 0,00 & 0,00 & 0,00 & 0,00 & 0,07 & 0,00 & 0,00 & 0,00 & 0,00 & 0,06 & 0,00 & 0,05 & 0,00 \\
\hline 044 & Milho & 5,89 & 2,86 & 3,48 & 4,82 & 0,94 & 3,17 & 8,06 & 4,19 & 5,31 & 7,10 & 5,67 & 11,39 & 13,92 & 9,96 & 14,99 & 11,02 \\
\hline 045 & Cereais & 0,02 & 0,07 & 2,03 & 0,90 & 0,18 & 0,09 & 1,28 & 0,07 & 0,10 & 0,04 & 0,10 & 0,08 & 0,10 & 0,16 & 0,14 & 0,06 \\
\hline 054 & Produtos hortícolas & 0,07 & 0,07 & 0,04 & 0,03 & 0,03 & 0,04 & 0,09 & 0,03 & 0,06 & 0,02 & 0,04 & 0,05 & 0,04 & 0,07 & 0,11 & 0,07 \\
\hline 057 & Frutas e nozes & 1,31 & 1,31 & 1,43 & 1,38 & 1,26 & 1,20 & 1,38 & 1,18 & 1,04 & 0,90 & 0,77 & 0,77 & 0,69 & 0,66 & 0,73 & 0,65 \\
\hline 071 & Café & 17,18 & 17,31 & 16,11 & 16,55 & 16,59 & 16,12 & 15,33 & 14,75 & 14,27 & 14,83 & 14,58 & 12,34 & 11,88 & 14,43 & 14,33 & 12,77 \\
\hline 072 & Cacau & 2,35 & 2,43 & 2,85 & 2,23 & 2,49 & 2,18 & 2,00 & 1,69 & 1,24 & 1,28 & 1,05 & 1,02 & 0,88 & 1,05 & 1,38 & 1,30 \\
\hline 074 & Chá e mate & 1,20 & 1,10 & 0,74 & 0,66 & 0,75 & 0,80 & 0,81 & 0,77 & 0,74 & 0,71 & 0,85 & 0,99 & 1,02 & 1,51 & 1,51 & 1,21 \\
\hline 075 & Especiarias & 3,69 & 3,78 & 3,06 & 3,31 & 3,16 & 3,45 & 3,21 & 2,48 & 2,38 & 1,68 & 2,02 & 2,08 & 2,43 & 3,19 & 3,29 & 2,40 \\
\hline 081 & Material para alimentação de animais & 10,38 & 10,63 & 10,84 & 10,79 & 8,69 & 6,79 & 6,63 & 6,92 & 7,45 & 6,52 & 6,31 & 6,90 & 6,67 & 7,27 & 7,16 & 6,70 \\
\hline 091 & Margarina & 0,35 & 0,23 & 0,36 & 0,93 & 0,57 & 0,40 & 0,52 & 0,64 & 0,59 & 0,64 & 0,67 & 0,35 & 0,53 & 1,05 & 0,79 & 0,42 \\
\hline 121 & Tabaco manufaturado & 16,67 & 19,63 & 19,40 & 19,30 & 20,87 & 19,77 & 22,13 & 21,59 & 21,56 & 18,85 & 18,08 & 19,69 & 19,40 & 17,12 & 16,56 & 15,83 \\
\hline 211 & Couro cru e peles & 0,16 & 0,15 & 0,09 & 0,05 & 0,10 & 0,09 & 0,12 & 0,18 & 0,17 & 0,12 & 0,02 & 0,07 & 0,16 & 0,11 & 0,10 & 0,08 \\
\hline 212 & Peles com pelo & 0,00 & 0,00 & 0,00 & 0,00 & 0,01 & 0,01 & 0,02 & 0,03 & 0,02 & 0,02 & 0,01 & 0,01 & 0,00 & 0,00 & 0,00 & 0,00 \\
\hline 222 & Sementes e frutos oleaginosos & 19,91 & 21,76 & 21,73 & 24,09 & 22,17 & 21,97 & 18,23 & 17,82 & 20,40 & 15,34 & 17,79 & 17,60 & 22,27 & 24,63 & 26,49 & 24,05 \\
\hline 223 & Sementes e frutos oleaginosos (comestíveis) & 0,10 & 0,09 & 0,06 & 0,04 & 0,06 & 0,06 & 0,09 & 0,02 & 0,01 & 0,02 & 0,01 & 0,01 & 0,00 & 0,02 & 0,02 & 0,01 \\
\hline 232 & Látex de borracha natural & 0,00 & 0,01 & 0,01 & 0,01 & 0,00 & 0,00 & 0,01 & 0,01 & 0,03 & 0,09 & 0,08 & 0,10 & 0,02 & 0,02 & 0,04 & 0,03 \\
\hline 244 & Cortiça (madeira) & 0,01 & 0,01 & 0,00 & 0,00 & 0,01 & 0,01 & 0,00 & 0,01 & 0,00 & 0,00 & 0,00 & 0,00 & 0,00 & 0,00 & 0,00 & 0,00 \\
\hline 245 & Combustíveis de madeira & 0,87 & 0,74 & 0,60 & 1,09 & 0,66 & 0,44 & 0,43 & 0,17 & 0,20 & 0,09 & 0,03 & 0,03 & 0,04 & 0,04 & 0,10 & 0,09 \\
\hline 246 & Polpa (madeira) & 2,89 & 3,12 & 3,03 & 3,27 & 3,07 & 2,93 & 2,56 & 2,42 & 1,80 & 1,57 & 1,23 & 1,45 & 1,44 & 1,50 & 1,66 & 1,78 \\
\hline 261 & Seda & 0,64 & 0,84 & 0,80 & 0,55 & 0,56 & 0,34 & 0,26 & 0,19 & 0,15 & 0,17 & 0,11 & 0,07 & 0,13 & 0,12 & 0,14 & 0,21 \\
\hline 263 & Algodão & 2,63 & 1,69 & 2,41 & 3,72 & 4,48 & 3,16 & 4,23 & 5,29 & 6,70 & 4,25 & 5,40 & 7,90 & 4,73 & 7,92 & 10,30 & 9,69 \\
\hline 268 & Lã e pelos de animais & 0,19 & 0,20 & 0,25 & 0,17 & 0,16 & 0,19 & 0,19 & 0,22 & 0,47 & 0,36 & 0,28 & 0,41 & 0,50 & 0,52 & 0,58 & 0,47 \\
\hline 271 & Fertilizantes & 0,03 & 0,05 & 0,10 & 0,10 & 0,06 & 0,06 & 0,08 & 0,03 & 0,04 & 0,08 & 0,10 & 0,15 & 0,15 & 0,16 & 0,13 & 0,12 \\
\hline 273 & Pedra, areia, cascalho. & 1,17 & 1,29 & 2,55 & 2,24 & 2,40 & 2,46 & 2,09 & 1,51 & 1,42 & 2,00 & 1,85 & 1,88 & 2,11 & 1,98 & 1,84 & 1,90 \\
\hline 274 & Poleias de ferro & 0,02 & 0,04 & 0,02 & 0,02 & 0,07 & 0,03 & 0,02 & 0,01 & 0,03 & 0,02 & 0,01 & 0,02 & 0,05 & 0,05 & 0,07 & 0,10 \\
\hline 277 & Abrasivos naturais & 0,03 & 0,04 & 0,45 & 0,63 & 0,29 & 0,03 & 0,03 & 0,05 & 0,02 & 0,03 & 0,03 & 0,03 & 0,03 & 0,05 & 0,04 & 0,09 \\
\hline 278 & Outros minerais brutos & 3,37 & 3,44 & 3,48 & 3,13 & 2,83 & 3,00 & 3,15 & 2,97 & 3,12 & 2,43 & 2,17 & 2,35 & 2,26 & 2,39 & 2,64 & 2,59 \\
\hline 291 & Materiais de animais brutos & 2,62 & 2,87 & 3,32 & 3,01 & 2,97 & 3,08 & 4,01 & 4,27 & 4,89 & 4,80 & 4,15 & 4,69 & 4,80 & 5,10 & 4,39 & 4,25 \\
\hline 292 & Materiais de vegetais brutos & 0,51 & 0,52 & 0,52 & 0,46 & 0,45 & 0,49 & 0,53 & 0,52 & 0,48 & 0,47 & 0,47 & 0,51 & 0,45 & 0,51 & 0,48 & 0,54 \\
\hline 322 & Carvão linhita e turfa & 0,00 & 0,00 & 0,00 & 0,00 & 0,00 & 0,00 & 0,00 & 0,00 & 0,00 & 0,00 & 0,00 & 0,00 & 0,00 & 0,00 & 0,00 & 0,00 \\
\hline 333 & Petróleo bruto e óleo de minerais betuminosos & 0,24 & 0,56 & 0,57 & 0,50 & 0,58 & 0,69 & 0,84 & 0,85 & 0,94 & 1,10 & 0,99 & 1,07 & 0,67 & 1,06 & 1,59 & 1,50 \\
\hline 341 & Gás natural manufaturado & 0,00 & 0,03 & 0,03 & 0,01 & 0,03 & 0,01 & 0,01 & 0,00 & 0,00 & 0,00 & 0,01 & 0,03 & 0,01 & 0,01 & 0,00 & 0,05 \\
\hline 681 & Prata, platina e outros metais. & 0,12 & 0,28 & 0,26 & 0,11 & 0,12 & 0,16 & 0,06 & 0,06 & 0,05 & 0,05 & 0,05 & 0,07 & 0,05 & 0,07 & 0,05 & 0,06 \\
\hline 682 & Cobre & 0,39 & 0,61 & 0,46 & 0,50 & 0,57 & 0,69 & 0,72 & 0,67 & 0,55 & 0,35 & 0,41 & 0,29 & 0,58 & 0,45 & 0,78 & 0,83 \\
\hline 683 & Níquel & 1,00 & 1,14 & 1,31 & 1,36 & 1,20 & 0,94 & 1,08 & 0,94 & 0,94 & 0,91 & 1,08 & 1,10 & 1,08 & 1,00 & 1,12 & 0,58 \\
\hline 684 & Alumínio & 2,46 & 2,72 & 2,70 & 2,53 & 2,13 & 2,36 & 2,23 & 1,82 & 1,70 & 1,22 & 0,97 & 0,93 & 0,78 & 0,73 & 0,69 & 0,66 \\
\hline 685 & Chumbo & 0,01 & 0,01 & 0,01 & 0,01 & 0,01 & 0,00 & 0,05 & 0,01 & 0,00 & 0,01 & 0,01 & 0,03 & 0,02 & 0,00 & 0,01 & 0,30 \\
\hline 686 & Zinco & 0,52 & 1,17 & 1,19 & 1,01 & 1,23 & 1,20 & 0,79 & 0,69 & 1,00 & 0,91 & 0,97 & 0,70 & 0,38 & 0,34 & 0,82 & 1,15 \\
\hline 687 & Estranho & 2,08 & 1,82 & 1,14 & 1,47 & 1,17 & 1,05 & 1,50 & 1,48 & 1,02 & 0,36 & 0,83 & 1,44 & 1,58 & 2,17 & 2,50 & 2,61 \\
\hline
\end{tabular}

Fonte: Elaboração própria com base em dados do UNCOMTRADE e do Trademap (2017)

Através da interpretação alternativa, que divide os resultados em graus de competitividade, proposta por Hinloopen e Marrewijk (2001), tem-se que, produtos como, sementes e frutos oleaginosos $(21,02)$, tabaco $(19,15)$, café $(14,96)$, carnes $(9,29)$ e material para alimentação de animais apresentaram vantagens comparativas reveladas fortes em todos os períodos a apresentaram na média para o período, os melhores resultados. Percebese também, que os produtos do setor mineral foram os que na média apresentaram os piores resultados.

Enquanto a Tabela 3 apresenta os resultados referentes a contribuição ao saldo comercial, em que a regiáo sombreada em cinza representa os setores que contribuem positivamente com o saldo comercial, e aquelas sombreadas em vermelho representa aqueles setores que apresentam contribuição negativa. $\mathrm{Na}$ média, os produtos que obtiveram os melhores resultados foram: sementes e frutos oleaginosos (6,39), carnes (5,39), material 
para alimentação de animais $(2,72)$, tabaco $(1,30)$ e milho $(1,05)$, os demais apresentaram um valor médio abaixo da unidade.

Em contrapartida, os produtos que apresentaram os piores resultados foram: gás natural $(-2,08)$, petróleo bruto $(-2,07)$, carvão $(-1,37)$ e o trigo $(-1,01)$. Percebe-se que, quando comparado aos demais indicadores, o CS possui resultados bem mais expressivos, evidenciando que embora alguns produtos não sejam tão competitivos, ou detentores de uma significativa do mercado internacional, eles ainda estão presentes em nossa pauta de exportaçóes. Isso ocorre, pois, contribuir com o saldo comercial não exige eficiência produtiva ou "poder no mercado", mas só que exista uma distância entre o fluxo de exportaçóes e o fluxo de importaçóes, de modo que, entre cada vez mais divisas com a venda de tal produto, ao mesmo que tempo que menos divisas sejam gastas com a compra desse mesmo produto.

É importante a se destacar que, de forma geral, os produtos com resultados mais significativos se tratavam de produtos do setor agropecuário, especialmente os grãos e animais vivos, além de conseguir manter estáveis, apresentado resultados positivos na maioria dos anos. Verifica-se também que culturas tradicionais, como o café, o tabaco e o algodão que historicamente desempenharam um papel importante para a balança comercial, apresentam resultados expressivos, juntamente com produtos que foram inseridos recentemente, como o complexo da soja e das carnes.

Percebe-se que um modelo de desenvolvimento centrado na produção de produtos intensivos em recursos naturais, como é caso das commodities, não tem sustentabilidade a longo prazo, dada a vulnerabilidade deste tipo de produtos à conjuntura externa e a alta volatilidade destes preços, assim como apontava Prebisch (2000) e Reinert (2016). Outro fator que evidencia a falta de sustentabilidade de um modelo de desenvolvimento baseado nas exportaçóes por meio de commodities é a intensidade dos ciclos de valoração dos preços desses produtos em comparação com os ciclos de desvalorização. Tal fato é evidenciado por Lima e Margarido (2008), que mostram que os ciclos de desvalorização dos preços desses produtos tendem a ser mais extensos que os ciclos de valoração. 
Tabela 3 - CS para produtos primários 2001-2016

\begin{tabular}{|c|c|c|c|c|c|c|c|c|c|c|c|c|c|c|c|c|c|}
\hline SITC & PRODUTO & 2001 & 2002 & 2003 & 2004 & 2005 & 2006 & 2007 & 2008 & 2009 & 2010 & 2011 & 2012 & 2013 & 2014 & 2015 & 2016 \\
\hline 001 & Animais vivos & $-0,03$ & $-0,05$ & 0,00 & 0,01 & 0,03 & 0,06 & 0,17 & 0,21 & 0,24 & 0,29 & 0,17 & 0,25 & 0,31 & 0,30 & 0,14 & 0,13 \\
\hline 011 & Carnes e miudezas comestíveis & 4,32 & 4,56 & 5,01 & 6,36 & 6,02 & 5,17 & 5,55 & 6,31 & 5,01 & 4,75 & 4,57 & 4,98 & 5,60 & 5,90 & 6,43 & 5,62 \\
\hline 022 & Leite e creme & $-0,25$ & $-0,42$ & $-0,15$ & $-0,03$ & $-0,07$ & $-0,06$ & 0,04 & 0,14 & $-0,06$ & $-0,06$ & $-0,13$ & $-0,16$ & $-0,13$ & $-0,01$ & $-0,02$ & $-0,23$ \\
\hline 025 & Ovos de pássaros & 0,02 & 0,00 & 0,00 & 0,00 & 0,00 & 0,00 & 0,01 & 0,04 & 0,04 & 0,04 & 0,03 & 0,03 & 0,02 & 0,03 & 0,03 & 0,01 \\
\hline 034 & Peixe fresco & $-0,09$ & $-0,10$ & $-0,11$ & $-0,13$ & $-0,11$ & $-0,18$ & $-0,19$ & $-0,20$ & $-0,26$ & $-0,26$ & $-0,30$ & $-0,30$ & $-0,38$ & $-0,42$ & $-0,46$ & $-0,52$ \\
\hline 036 & Crustáceos e moluscos & 0,33 & 0,43 & 0,45 & 0,36 & 0,24 & 0,17 & 0,10 & 0,08 & 0,04 & 0,04 & 0,02 & 0,01 & 0,02 & 0,02 & 0,03 & 0,02 \\
\hline 041 & Trigo & $-1,59$ & $-1,94$ & $-2,17$ & $-1,08$ & $-0,89$ & $-1,03$ & $-1,12$ & $-1,07$ & $-0,76$ & $-0,63$ & $-0,49$ & $-0,50$ & $-0,84$ & $-0,69$ & $-0,53$ & $-0,80$ \\
\hline 042 & Arroz & $-0,24$ & $-0,24$ & $-0,64$ & $-0,42$ & $-0,13$ & $-0,15$ & $-0,16$ & 0,03 & $-0,03$ & $-0,11$ & 0,11 & 0,07 & 0,01 & 0,04 & 0,09 & $-0,07$ \\
\hline 043 & Cevada & $-0,04$ & $-0,05$ & $-0,08$ & $-0,06$ & $-0,03$ & $-0,03$ & $-0,04$ & $-0,05$ & $-0,07$ & $-0,03$ & $-0,04$ & $-0,03$ & $-0,05$ & $-0,05$ & $-0,08$ & $-0,11$ \\
\hline 044 & Milho & 0,75 & 0,39 & 0,38 & 0,64 & 0,02 & 0,26 & 1,07 & 0,68 & 0,60 & 0,91 & 0,92 & 2,02 & 2,47 & 1,57 & 2,60 & 1,46 \\
\hline 045 & Cereais & $-0,03$ & $-0,04$ & 0,01 & $-0,01$ & $-0,02$ & $-0,01$ & 0,01 & $-0,02$ & $-0,01$ & $-0,01$ & $-0,01$ & $-0,01$ & $-0,01$ & $-0,01$ & $-0,01$ & $-0,01$ \\
\hline 054 & Produtos hortícolas & $-0,42$ & $-0,40$ & $-0,39$ & $-0,41$ & $-0,33$ & $-0,26$ & $-0,23$ & $-0,35$ & $-0,26$ & $-0,36$ & $-0,31$ & $-0,33$ & $-0,43$ & $-0,31$ & $-0,40$ & $-0,70$ \\
\hline 057 & Frutas e nozes & 0,29 & 0,35 & 0,46 & 0,42 & 0,28 & 0,19 & 0,28 & 0,27 & 0,17 & 0,11 & 0,01 & 0,00 & 0,02 & $-0,02$ & 0,04 & $-0,06$ \\
\hline 071 & Café & 2,47 & 2,39 & 2,20 & 2,42 & 2,51 & 2,42 & 2,39 & 2,61 & 2,33 & 2,46 & 3,11 & 2,49 & 2,11 & 2,71 & 3,18 & 2,56 \\
\hline 072 & Cacau & 0,10 & 0,01 & 0,04 & 0,12 & 0,08 & 0,05 & 0,01 & 0,04 & $-0,01$ & 0,03 & 0,04 & $-0,01$ & 0,04 & 0,03 & 0,10 & $-0,01$ \\
\hline 074 & Chá e mate & 0,05 & 0,04 & 0,03 & 0,02 & 0,02 & 0,02 & 0,02 & 0,03 & 0,02 & 0,02 & 0,02 & 0,03 & 0,04 & 0,05 & 0,05 & 0,04 \\
\hline 075 & Especiarias & 0,13 & 0,14 & 0,08 & 0,08 & 0,06 & 0,08 & 0,07 & 0,07 & 0,06 & 0,04 & 0,07 & 0,07 & 0,09 & 0,14 & 0,17 & 0,11 \\
\hline 081 & Material para alimentação de animais & 3,62 & 3,70 & 3,60 & 3,79 & 2,40 & 1,72 & 1,82 & 2,45 & 2,55 & 2,07 & 2,06 & 2,58 & 2,76 & 2,91 & 3,07 & 2,47 \\
\hline 091 & Margarina & 0,01 & 0,01 & 0,01 & 0,03 & 0,01 & 0,00 & $-0,01$ & 0,00 & $-0,01$ & $-0,01$ & 0,00 & 0,00 & 0,00 & 0,01 & $-0,02$ & $-0,04$ \\
\hline 121 & Tabaco manufaturado & 1,57 & 1,64 & 1,46 & 1,60 & 1,40 & 1,19 & 1,32 & 1,45 & 1,59 & 1,13 & 1,02 & 1,23 & 1,27 & 0,98 & 1,09 & 0,95 \\
\hline 211 & Couro cru e peles & 0,01 & $-0,02$ & $-0,02$ & $-0,01$ & $-0,01$ & 0,00 & 0,00 & 0,00 & 0,00 & 0,00 & 0,00 & 0,00 & 0,01 & 0,00 & 0,00 & 0,00 \\
\hline 212 & Peles com pelo & 0,00 & 0,00 & 0,00 & 0,00 & 0,00 & 0,00 & 0,00 & 0,00 & 0,00 & 0,00 & 0,00 & 0,00 & 0,00 & 0,00 & 0,00 & 0,00 \\
\hline 222 & Sementes e frutos oleaginosos & 4,51 & 4,85 & 5,62 & 6,25 & 4,52 & 4,07 & 4,10 & 6,02 & 6,24 & 4,73 & 5,87 & 6,67 & 9,16 & 9,49 & 11,01 & 9,17 \\
\hline 223 & Sementes e frutos oleaginosos (comestíveis) & 0,00 & 0,00 & $-0,01$ & $-0,01$ & 0,00 & 0,00 & 0,00 & 0,00 & $-0,01$ & $-0,01$ & $-0,01$ & $-0,01$ & $-0,01$ & $-0,01$ & $-0,01$ & $-0,01$ \\
\hline 232 & Látex de borracha natural & $-0,15$ & $-0,23$ & $-0,34$ & $-0,43$ & $-0,37$ & $-0,42$ & $-0,39$ & $-0,42$ & $-0,18$ & $-0,36$ & $-0,43$ & $-0,26$ & $-0,26$ & $-0,20$ & $-0,20$ & $-0,20$ \\
\hline 244 & Cortiça (madeira) & 0,00 & 0,00 & 0,00 & 0,00 & 0,00 & 0,00 & 0,00 & 0,00 & 0,00 & 0,00 & 0,00 & 0,00 & 0,00 & 0,00 & 0,00 & 0,00 \\
\hline 245 & Combustíveis de madeira & 0,00 & 0,00 & 0,00 & 0,00 & 0,00 & 0,00 & 0,00 & $-0,01$ & 0,00 & $-0,01$ & 0,00 & 0,00 & 0,00 & 0,00 & 0,00 & 0,00 \\
\hline 246 & Polpa (madeira) & 0,08 & 0,09 & 0,09 & 0,10 & 0,09 & 0,08 & 0,07 & 0,08 & 0,05 & 0,05 & 0,04 & 0,05 & 0,05 & 0,05 & 0,07 & 0,07 \\
\hline 261 & Seda & 0,00 & 0,00 & 0,00 & 0,00 & 0,00 & 0,00 & 0,00 & 0,00 & 0,00 & 0,00 & 0,00 & 0,00 & 0,00 & 0,00 & 0,00 & 0,00 \\
\hline 263 & Algodão & 0,11 & 0,03 & $-0,01$ & 0,19 & 0,33 & 0,14 & 0,21 & 0,35 & 0,37 & 0,32 & 0,42 & 0,82 & 0,43 & 0,53 & 0,67 & 0,56 \\
\hline 268 & Lã e pelos de animais & 0,01 & 0,01 & 0,01 & 0,00 & 0,00 & 0,00 & 0,00 & 0,00 & 0,01 & 0,01 & 0,01 & 0,01 & 0,01 & 0,01 & 0,02 & 0,01 \\
\hline 271 & Fertilizantes & $-0,10$ & $-0,11$ & $-0,12$ & $-0,14$ & $-0,09$ & $-0,08$ & $-0,09$ & $-0,20$ & $-0,06$ & $-0,07$ & $-0,09$ & $-0,10$ & $-0,10$ & $-0,09$ & $-0,14$ & $-0,11$ \\
\hline 273 & Pedra, areia, casc & 0,07 & 0,08 & 0,16 & 0,15 & 0,13 & 0,14 & 0,12 & 0,09 & 0,07 & 0,09 & 0,08 & 0,08 & 0,10 & 0,09 & 0,09 & 0,08 \\
\hline 274 & Poleias de ferro & $-0,09$ & $-0,11$ & $-0,22$ & $-0,24$ & $-0,15$ & $-0,11$ & $-0,14$ & $-0,65$ & $-0,13$ & $-0,12$ & $-0,18$ & $-0,17$ & $-0,12$ & $-0,12$ & $-0,18$ & $-0,12$ \\
\hline 277 & Abrasivos naturais & $-0,01$ & $-0,02$ & $-0,01$ & 0,00 & $-0,01$ & $-0,01$ & $-0,01$ & 0,00 & 0,00 & 0,00 & 0,00 & 0,00 & 0,00 & 0,00 & 0,00 & 0,00 \\
\hline 278 & Outros minerais brutos & 0,28 & 0,28 & 0,26 & 0,24 & 0,16 & 0,18 & 0,18 & 0,20 & 0,16 & 0,12 & 0,09 & 0,10 & 0,09 & 0,12 & 0,13 & 0,10 \\
\hline 291 & Materiais de animais brutos & 0,07 & 0,08 & 0,09 & 0,07 & 0,06 & 0,06 & 0,08 & 0,11 & 0,11 & 0,12 & 0,11 & 0,15 & 0,19 & 0,19 & 0,14 & 0,10 \\
\hline 292 & Materiais de vegetais brutos & $-0,03$ & $-0,05$ & $-0,02$ & $-0,04$ & $-0,04$ & $-0,02$ & 0,00 & 0,02 & $-0,01$ & 0,00 & 0,00 & 0,00 & $-0,01$ & $-0,01$ & $-0,04$ & $-0,04$ \\
\hline 322 & Carvão linhita e turfa & $-1,04$ & $-1,40$ & $-1,39$ & $-1,61$ & $-1,81$ & $-1,61$ & $-1,25$ & $-1,75$ & $-1,35$ & $-1,40$ & $-1,74$ & $-1,27$ & $-1,00$ & $-0,93$ & $-1,20$ & $-1,13$ \\
\hline 333 & Petróleo bruto e óleo de minerais betuminosos & $-4,59$ & $-4,26$ & $-5,18$ & $-9,29$ & $-7,03$ & $-4,88$ & $-4,34$ & $-2,90$ & $-0,92$ & 2,18 & 2,03 & 2,23 & $-1,42$ & 0,45 & 1,86 & 2,93 \\
\hline 341 & Gás natural manufaturado & $-1,40$ & $-1,60$ & $-1,57$ & $-1,76$ & $-1,42$ & $-1,90$ & $-1,71$ & $-2,34$ & $-1,54$ & $-1,92$ & $-1,84$ & $-2,46$ & $-3,27$ & $-3,39$ & $-3,46$ & $-1,68$ \\
\hline 681 & Prata, platina e outros metais. & $-0,41$ & $-0,24$ & $-0,58$ & $-0,78$ & $-0,78$ & $-1,10$ & $-1,04$ & $-0,97$ & $-0,53$ & $-0,90$ & $-0,78$ & $-0,87$ & $-0,51$ & $-0,47$ & $-0,47$ & $-0,28$ \\
\hline 682 & Cobre & $-0,03$ & $-0,06$ & $-0,15$ & $-0,09$ & $-0,03$ & 0,01 & 0,05 & 0,04 & 0,04 & 0,05 & 0,07 & 0,07 & 0,08 & 0,08 & 0,09 & $-0,01$ \\
\hline 683 & Níquel & 1,23 & 1,47 & 1,49 & 1,61 & 1,18 & 1,57 & 1,37 & 1,10 & 0,62 & 0,37 & 0,11 & 0,13 & 0,06 & $-0,21$ & $-0,30$ & $-0,24$ \\
\hline 684 & Alumínio & $-0,07$ & $-0,08$ & $-0,06$ & $-0,11$ & $-0,11$ & $-0,11$ & $-0,12$ & $-0,13$ & $-0,09$ & $-0,09$ & $-0,08$ & $-0,07$ & $-0,08$ & $-0,06$ & $-0,07$ & $-0,07$ \\
\hline 685 & Chumbo & $-0,03$ & 0,05 & 0,03 & 0,01 & 0,04 & 0,06 & $-0,01$ & $-0,01$ & 0,02 & 0,01 & 0,01 & $-0,01$ & $-0,01$ & 0,00 & 0,02 & 0,03 \\
\hline 686 & Zinco & 0,04 & 0,03 & 0,01 & 0,03 & 0,01 & 0,01 & 0,03 & 0,05 & 0,02 & 0,01 & 0,02 & 0,05 & 0,06 & 0,07 & 0,07 & 0,06 \\
\hline 687 & Estranho & 0,00 & 0,00 & 0,00 & 0,00 & 0,00 & 0,00 & 0,00 & 0,00 & 0,00 & 0,00 & 0,00 & 0,00 & 0,00 & 0,00 & 0,00 & 0,00 \\
\hline
\end{tabular}

Fonte: Elaboraçáo própria com base em dados do UNCOMTRADE e do Trademap (2017)

\section{CONSIDERAÇÓES FINAIS}

Com base no que foi visto a respeito do papel da especialização comercial para o caso brasileiro, pode-se dizer que problemas antigos ainda não foram superados que é a relação da economia brasileira com os produtos primários ainda é uma relação forte, marcada pela dependência de fatores externos, algo que o país ainda não foi capaz de superar.

Quanto ao fato da especializaçáo comercial em produtos de baixo valor agregado ser apenas um estágio, parece não se aplicar à experiência brasileira nos anos recentes, tendo em vista que a inserção baseada em produtos em sua maioria in natura, além de produtos "tradicionais" que se mantêm com relativa importância desde o período colonial. 
Quanto aos resultados dos indicadores do setor primário brasileiro, percebe-se que os produtos primários brasileiros apresentam bons resultados para os indicadores de comércio internacional. Temos produtos como sementes e frutos oleaginosos, tabaco e café, que representaram em média cerca de $1 / 5$ do comércio mundial, além de serem extremamente competitivos. Mais da metade dos produtos contribuíram positivamente com o saldo comercial.

Pode-se dizer que há evidência não só de intensificação da participação de produtos primários na pauta de exportações brasileira, como também, verifica-se um processo de concentraçấo dessa mesma pauta, onde poucos produtos respondem por um alto percentual de participaçáo nos mercados externos, passam a se tornar cada vez mais competitivos e obter mais espaço dentro da balança comercial brasileira.

O setor de produtos primários é um setor muito forte dentro da economia brasileira, onde quase metade de seus produtos apresentam resultados, que a curto prazo torna rentável o investimento, vide os resultados de $M S$, competitividade e contribuição ao saldo comercial obtidos através dos indicadores de comércio internacional. O problema é que além desses possuírem uma baixa elasticidade renda e usufruir de forma menos efetiva dos benefícios $\mathrm{da}$ inovação tecnológica, à longo prazo esses produtos são mais sensíveis à choques externos e em situaçôes adversas em um curto espaço de tempo perdem boa parte de sua rentabilidade.

Com isso, é possível concluir que o Brasil parece preso a um círculo vicioso comum a países produtores de produtos primários, embora tenha passado por um processo de industrialização que dinamizou o setor produtivo, sempre que há oportunidade se volta para o setor primário. Nesta situaçáo cabe destacar que um modelo de desenvolvimento centrado na produção e comercializaçáo de produtos primários não foi capaz de promover o desenvolvimento do país, assim como foi defendido por Prebisch e os demais pensadores da escola cepalina, o país precisa migrar suas atençôes e recursos para setores mais dinâmicos, que usufruem de forma mais proveitosa dos benefícios advindos do progresso tecnológico.

Quanto as limitaçóes do trabalho, destaca-se o recorte setorial, visto que, ao mesmo tempo que uma análise centrada nos produtos primários possibilita a visualização do comportamento do setor, bem como seu suas particularidades, seria interessante uma análise comparativa entre dois ou mais setores. Dessa forma, sugere-se para trabalhos futuros a análise dos demais setores, bem como uma comparação entre os mesmos, além da utilização de metodologias que possibilitem inferências/previsóes acerca dos dados, como instrumentais econométricos. Contudo, espera-se que esse trabalho contribua com o debate, assim como com a elaboração/avaliação de políticas públicas.

\section{REFERÊNCIAS}

ABREU, Marcelo de Paiva; LAGO, Luiz. A. C de. A economia brasileira no império. In: ABREU, Marcelo de Paiva (Org.). A ordem do progresso: dois séculos de política econômica no Brasil. 2. ed. Rio de Janeiro: Elsevier, 2014. Cap. 1, p. 5-18.

AMARAL, Felipe; FREITAS, Fabio; CASTILHO, Marta. Comércio internacional, especialização produtiva e competitividade: uma decomposição para o crescimento das 
exportações brasileiras entre 1995 e 2014 . XXII Encontro Nacional de Economia Política. p.10. Disponível em: <ttps://www.researchgate.net/publication/317540152_ Comercio_internacional_especializacao_produtiva_e_competitividade_uma_ decomposicao_para_o_crescimento_das_exportacoes_brasileiras_entre_1995_e_2014> Acesso em: Set. 2016.

ANTONIO FILHO, Fadel David. Riqueza e miséria do ciclo da borracha na Amazônia brasileira: um olhar geográfico por intermédio de Euclides da Cunha. História do pensamento geográfico e epistemologia em Geografia [online]. Sáo Paulo: Editora UNESP, p. 187-207, 2010.

BALASSA, B. Trade liberalisation and "revealed" comparative advantage. The Manchester School of Economic and Social Studies, v. 32, n. 2, p. 99-123, 1965.

BANCO CENTRAL DO BRASIL. Boletim do Banco Central do Brasil. Departamento Econômico do Banco Central do Brasil, 2003.

BRESSER-PEREIRA, L. C.; MARCONI, N. Existe doença holandesa no Brasil? In: Anais do IV Fórum de Economia de São Paulo. São Paulo, 2008.

BRESSER-PEREIRA, Luiz Carlos. A revolução capitalista. 2016.

COLISTETE, Renato Perim. O desenvolvimentismo cepalino: problemas teóricos e influências no Brasil. Estudos avançados, v. 15, n. 41, p.24. 2001.

FOURQUIN, Guy; BARÃO, Fernanda. História econômica do ocidente medieval. 1981.

FURTADO, C.. Formação econômica do Brasil. São Paulo, 14a Ed., Cia. Ed. Nacional, 1977.

GIL, Antônio Carlos. Como classificar as pesquisas. Como elaborar projetos de pesquisa, v. 4, p. 44-45, 2002.

GODINHO, Daniel Marteleto. Balança comercial registra em 2014 primeiro déficit desde 2000. G1. Disponível em:< http://g1.globo.com/economia/noticia/2015/01/ balanca-comercial-registra-em-2014-primeiro-deficit-desde-2000.html>. Acesso em: Ago.2017.

HINLOOPEN, J.; MARREWIJK, C. V. On the empirical distribution of the Balassa Index. Weltwirtschaftliches Archiv, v. 137, n. 1, p. 1-35, 2001.

ITAÚ. Nossas Séries Econômicas. ICI Commodities. Disponível em: <https://www.itau. com.br/itaubba-pt/analises-economicas/nossas-series-economicas/ici-commodities>. Acesso em: Jul.2017. 
KRUGMAN, P. R.; OBSTFELD, M. Economia internacional: teoria e política. São Paulo: Pearson Prentice Hall, 2010. p. 1.

LALL, S. (2000) “The technological structure and performance of developing country manufactured exports, 1985-1998”. Oxford Development Studies, v. 28, n. 3: 337-369.

LANNONE, Roberto. A CEPAL e o pensamento econômico Latino-Americano. In: BRUE, Stanley L, (Org.) História do Pensamento Econômico. 6ª ed. São Paulo: Thomson Pioneira, 2006. p. 515-527.

LIMA, L. A. F.; MARGARIDO, M. A. Causas do atual ciclo de alta de preços de Commodities. Análises e Indicadores do Agronegócio, São Paulo, v. 3, n. 7, 2008.

Disponível em:<http://www.iea.sp.gov.br/ftpiea/AIA/AIA-59-2008.pdf> . Acesso em: 15 set. 2016.

MAPA, Ministério da Agricultura, Pecuária e Abastecimento. Intercâmbio comercial do agronegócio: principais mercados de destino. Brasília: MAPA/ACS, 2011. Acesso em: Dez.2018.

MDIC. Outras estatísticas de comércio exterior. Disponível em: <http://www.mdic.gov. $\mathrm{br} /$ index.php/ comercio-exterior/estatisticas-de-comercio-exterior/outras-estatisticas-decomercio-exterior>. Acesso em: Ago.2017

OLIVEIRA, I. T. M. Livre Comércio versus Protecionismo: uma análise das principais teorias do Comércio internacional. Revista Urutágua, Paraná, 2007.

OREIRO, José Luis; FEIJÓ, Carmem A. Desindustrialização: conceituação, causas, efeitos e o caso brasileiro. Revista de economia política, v. 30, n. 2, p. 219-232, 2010.

PEREIRA, V, Lia. O Brasil é uma economia fechada?. Revista Conjuntura Econômica, v. 71, n. 1, p. 56-59, 2017.

POYER, M, G; RORATTO, P. Introdução ao comércio exterior. Palhoça :

UnisulVirtual, 2017.

PRATES, Daniela Magalhães et al. A alta recente dos preços das Commodities. Revista de Economia Política, 2007.

PREBISCH, Raúl. O desenvolvimento econômico da América Latina e alguns de seus problemas principais. In: Cinqüenta anos de pensamento na CEPAL. Rio de Janeiro: Record/CEPAL, 2000-v. 1, p. 69-136, 2000.

RAMOS, Pedro. A EVOLUÇÃO (EXCLUDENTE E DESIGUAL) DA PRODUÇÃO AGRÍCOLA BRASILEIRA ENTRE 1930 E 2007: Do mercado interno para o externo. 2009. Disponível em: <http://www.abphe.org.br/arquivos/pedro-ramos_1.pdf>. Acesso em: 03 out. 19. 
REINERT, Erick S. COMO OS PAÍSES RICOS FICARAM RICOS...E POR QUE OS PAÍSES POBRES CONTINUAM POBRES. 1. Ed. Rio de Janeiro: Contraponto, P.335. 2016. 435p.

RICARDO, David. Principles of political economy and taxation. G. Bell, 1891.

SARQUIS, Sarquis José Bauiainain. Comércio internacional e crescimento econômico no Brasil. Fundação Alexandre de Gusmão, 2011.

SCHMIDT FILHO, Ricardo; DA CRUZ LIMA, Bianca Guaracy Carvalho. Padrão de especializaçáo e competitividade internacional dos BRICS: 1985-2012. Revista Economia Ensaios, v. 28, n. 2.2014.

SMITH, Adam; STEWART, Dugald. An Inquiry into the Nature and Causes of the Wealth of Nations. Homewood, Ill: Irwin, 1963.

THE WORLD BANK. DATA WORLD BANK. Disponível em: <https://data.worldbank.org/indicator/SI.POV.

NAHC? end=2014\&locations=BR\&start=2003\&view=chart $>$. Acesso em: Ago.2017.

TRADEMAP. Trade statistics for international business development. Disponível em: <https://www.trademap.org/Index.aspx>. Acesso em: Jan.2017.

UNCOMTRADE, U. N. United Nations commodity trade statistics database. Disponível em: <https://comtrade.un.org/data/>. Acesso em: Jan.2017.

VILLELA, Annibal V.; SUZIGAN, Wilson. Política do governo e crescimento da economia brasileira, 1889-1945. IPEA/INPES, 1975. 